\title{
VASCULAR DEMENTIA REVISED
}

\section{VASKULARNA DEMENCIJA: REVIZIJA}

\author{
Nenad Đukić, Mihailo Nešković', Milorad Ševković', Đorđe Radak ${ }^{1,23}$
}

\section{Summary}

Vascular dementia is the second leading cause of dementia, right after Alzheimer's disease. It is a condition with great medical, social and economic burden. Although its concept has been recognized for over a century, disease mechanisms, diagnostic criteria and treatment modalities remain unclear and generate confusion and debate.

Dementia and cerebrovascular disease share risk factors and neuropathology, and may contribute to VaD. Several mechanisms have been proposed, including vascular risk factors (hypertension, diabetes, hyperlipidemia) and behavioral factors (physical inactivity, obesity) as major substrate for both cerebrovascular disease and dementia. Also, macro and micro-embolic events and chronic brain hypoperfusion contribute to vascular dementia .

Having in mind that disease mechanisms for vascular dementia and Alzheimer's disease are overlapping, and that clinical manifestations of cognitive impairment are often very similar, setting the diagnosis of vascular dementia is not an easy task. In clinical research, various diagnostic criteria are proposed. They are based on two major requirements: clinical diagnosis of dementia and its vascular origin.

According to its multicausal nature, vascular dementia stands as a difficult condition to treat. Several therapeutic modalities have been offered; however, further investigation and trials with long-term follow-up are needed.

Keywords: Vascular dementia, vascular cognitive impairment, cerebrovascular disease, carotid disease, carotid surgery

\section{Sažetak}

Vaskularna demencija je drugi vodeći uzrok demencije, odmah nakon Alzheimerove bolesti. To je stanje od velikog medicinskog, društvenog i ekonomskog značaja. lako je njen koncept prepoznat pre više od jednog veka, mehanizmi bolesti, dijagnostički kriterijumi i način lečenja ostaju nejasni, te izazivaju konfuziju i debatu.

Demencija i cerebrovaskularna bolest dele faktore rizika i neuropatologiju, doprinoseći razvoju vaskularne demencije. Vaskularni faktori rizika (hipertenzija, dijabetes, hiperlipidemija) i navike ponašanja (fizička neaktivnost, gojaznost), predstavljaju glavni supstrat za nastanak kako cerebrovaskularne bolesti, tako i demencije. Isto tako, makro i mikro-embolijski događaji u moždanoj cirkulaciji i hronična hipoperfuzija mozga doprinose nastanku vaskularne demencije.

Imajući u vidu da se mehanizmi bolesti vaskularne demencije i Alzheimerove bolesti preklapaju, te da su kliničke manifestacije kognitivnog oštećenja veoma slične, postavljanje prave dijagnoze često nije lak zadatak. U kliničkim istraživanjima su predloženi različiti dijagnostički kriterijumi, zasnovani na dva glavna principa: klinička dijagnoza demencije i njeno vaskularno poreklo.

Zbog svoje multikauzalne prirode, vaskularna demencija predstavlja zahtevno stanje za lečenje. Nekoliko terapijskih modaliteta je ponuđeno, međutim, potrebna su dalja istraživanja i studije sa dugoročnimpraćenjem.

Ključne reči: vaskularna demencija, vaskularno kognitivno oštećenje, cerebrovaskularna bolest, karotidna bolest, karotidna hirurgija

\section{INTRODUCTION}

Vascular dementia $(\mathrm{VaD})$ is the second leading cause of dementia, right after Alzheimer's disease (AD) $(1,2)$. In addition, postmortem pathological studies indicate that $15 \%$ to $34 \%$ of all dementia cases show a significant vascular pathology, either alone or in combination with $\mathrm{AD}(3)$.

Although its concept has been recognized for over a century, disease mechanisms, diagnostic criteria and treatment of $\mathrm{VaD}$ remain unclear and generate confusion and debate, despite the fact that several clinical criteria have been used for defining $\mathrm{VaD}$ (4). Given its growing health, social and economic burden, prevention and treatment of $\mathrm{VaD}$ are critical priorities for clinical care and research (5).
In order to illuminate this entity, we reviewed current literature and summarized previous findings related to VaD.

\section{DEFINING TERMS}

The term vascular dementia substantially means "disease with a cognitive impairment resulting from cerebrovascular disease and ischemic or hemorrhagic brain injury" (4). Recently, the term vascular cognitive impairment (VCI) was introduced to comprise the heterogeneous group of cognitive disorders that share a presumed vascular cause and to include both dementia and cognitive impairment without dementia (5). While some authors advocate that $\mathrm{VaD}$ and $\mathrm{VCI}$ are different terms for the same entity, for the majority VCI represents a much wider field of cognitive dysfunction (Table 1) (4, 6-11). 
Table 1. Types of vascular cognitive impairment

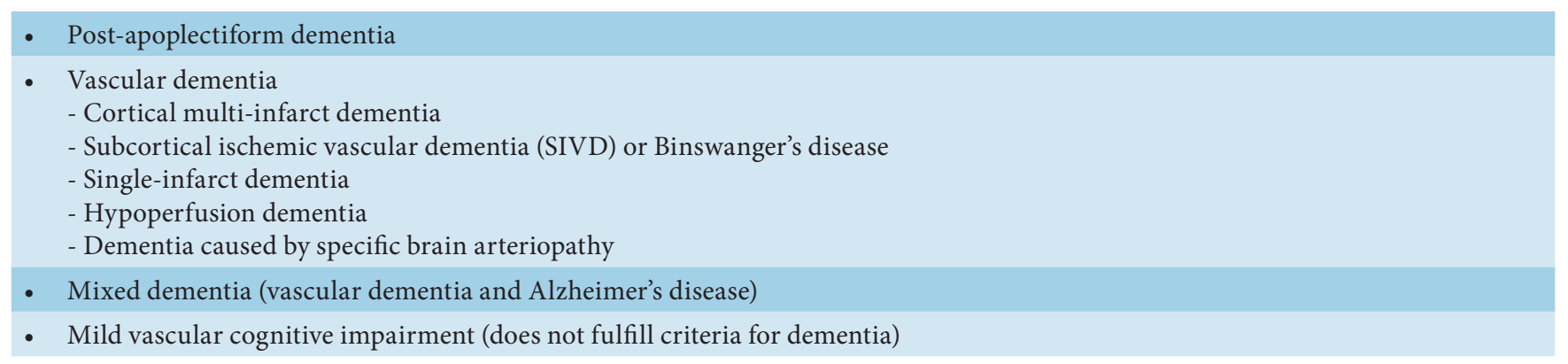

Subcortical ischemic vascular dementia (SIVD) or Binswanger's disease, represents one of the most common forms of $\mathrm{VaD}$, especially in the elderly (12). Cerebral autosomal dominant arteriopathy with subcortical infarcts and leukoencephalopathy (CADASIL), a subtype of SIVD, is a rare disease with the onset occurring between 40 and 50 years of age, and it's the most frequent hereditary cause of SIVD (13). As symptoms in CADASIL develop several decades before the onset of common degenerative diseases, confounding by concomitant medical conditions is considerably reduced (14). Therefore, CADASIL stands as a model of "pure" vascular dementia $(13,14)$.

\section{Disease mechanisms}

Dementia and cerebrovascular disease (CVD) share risk factors and neuropathology, and may contribute to $\mathrm{VaD}$ (15). Vascular risk factors (hypertension, diabetes, hyperlipidemia) and behavioral factors (physical inactivity, obesity) are associated with both CVD and dementia (Figure 1) (16, 17). Additionally, observational studies in middle-aged and older adults have found association between $\mathrm{VaD}$ and hypertension $(18,19)$, diabetes $(20,21)$, hyperlipidemia (22), physical inactivity (23) and obesity (24). Also, insulin resistance, abdominal obesity, dysfunction of the cerebral small-vessel endothelium (i.e. the blood brain barrier) and chronic kidney disease may contribute to or accelerate $\mathrm{VaD}$ (25-28).

Vascular risk factors may lead to cerebrovascular dysfunction through pathways mediated by beta-amyloid and the enzyme nicotinamide adenine dinucleotide phosphate (NADPH) oxidase, a major source of vascular oxidative stress (29). Several pathogenic mechanisms including $\mathrm{AD}$, amyloid deposition, hypertension, atherosclerosis and aging may converge to cause CVD and $\mathrm{VaD}$ through pathways of intravascular oxidative stress and inflammation $(25,29-31)$.

Moreover, observational studies suggest potential role of inflammation in $\mathrm{VaD}$. In a Japanese case-control study, elevated high sensitivity C-reactive protein and antibodies for Chlamydia pneumoniae were more prevalent in $\mathrm{VaD}$ than $\mathrm{AD}$ (32). A cross-sectional study found that high interleukin-6 plasma levels were associated with functional impairment in older adults with $\mathrm{VaD}$, but not late-onset $\mathrm{AD}(33)$.

Cerebrovascular dysfunction, including blood brain barrier alteration, may compromise cerebral microenvironment and increase the vulnerability of regions critical for cognition (e.g. subcortical white matter, neocortex, hippocampus) to hypoxic-ischemic brain damage, leading to neuronal function failure and cognitive impairment (29). Whether due to shared or additive vascular effects (34), CVD and dementia coexist frequently, particularly in the elderly (35-37).

Atrial fibrillation is known to cause macro-embolic complications, such as stroke, but it may also cause micro-embolic complications, leading to CVD, followed by cognitive impairment (38) or $\mathrm{VaD}$ (39). Also, hematologic factors may have an etiological role in $\mathrm{VaD}$. Recent

\section{Figure 1. Disease mechanisms of vascular dementia}

\section{Hypertension}

Diabetes

Hyperlipidemia

Physical inactivity

Obesity
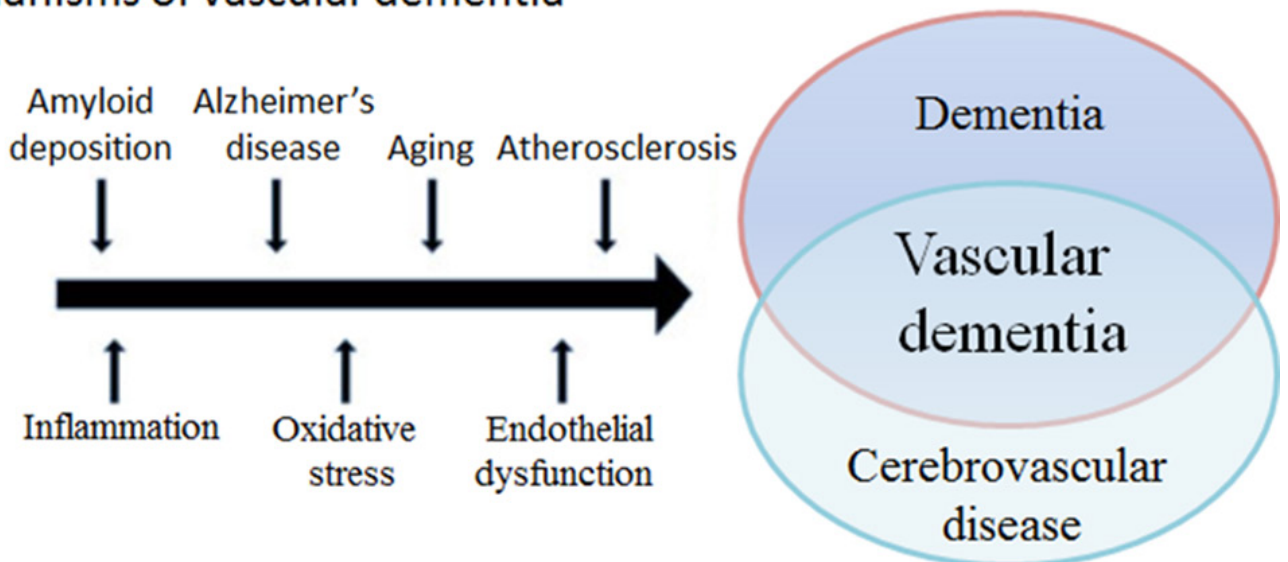
data may implicate clot formation and micro-infarctions as mechanisms of $\mathrm{VaD}$ through hemostatic pathways. High levels of fibrinogen, factor VIII, or plasminogen activation inhibitor 1 have been associated with an increased risk of VCI $(40,41)$.

Genetic factors may influence the development or course of VCI. Mutations of the Notch 3 gene on chromosome 19 are leading to CADASIL appearance (42). The apolipoprotein E epsilon 3 polymorphism (43) and the epsilon 4 polymorphism (44), particularly in persons with hypertension or diabetes (45), may be associated with an increased VCI risk, but the data are not conclusive $(46,47)$. The identification of quantifiable phenotypes that can be reliably and effectively determined in large samples of subjects is the greatest challenge for genetic studies of $\mathrm{VaD}(48)$.

Advanced carotid disease and $\mathrm{VaD}$ share multiple vascular risk factors (49). The connection between carotid artery stenosis/occlusion and cerebral hemodynamics has been recognized by Spencer and Reid (50). According to the known "Spencer curve", in mild and moderate carotid stenosis, brain blood perfusion remains stable, until high-grade carotid stenosis occurs (51). Besides cerebral microembolisation, proposed mechanisms of VCI and $\mathrm{VaD}$ in patients with advanced carotid disease thus include chronic hypoperfusion (49). A number of previous studies suggested that in asymptomatic individuals, severe carotid disease might be associated with subtle cognitive changes, but the results of those studies have not been consistent (47-56). As the current data on this topic are quite heterogeneous, they need further investigation.

\section{DiAgnOSTIC CRITERIA}

Having in mind that disease mechanisms for $\mathrm{VaD}$, $\mathrm{VCI}$ and $\mathrm{AD}$ overlap and that clinical manifestations of cognitive impairment are often very similar, setting the diagnosis of $\mathrm{VaD}$ is not an easy task. In clinical research, various criteria are proposed for the diagnosis of $\mathrm{VaD}$. They are based on two major requirements: clinical diagnosis of dementia and its vascular origin. The latter requirement is more problematic because of the frequent overlap between cerebrovascular and degenerative disorders, particularly in the elderly. The different set of criteria require various neuroimaging evidence of cerebrovascular disease, focal neurological signs or history of stroke with a temporal relationship with dementia (57).

Four sets of criteria have been essentially used for diagnosing $\mathrm{VaD}$ :

- National Institute of Neurological Disorders and Stroke Association Internationale pour la Recherche et l'Enseignement en Neurosciences (NINDS-AIREN) criteria, (58)
- Alzheimer's Disease Diagnostic and Treatment Centers (ADDTC), (59)

- International Statistical Classification of Diseases, 10th revision (ICD 10), (60) and

- Diagnostic and Statistical Manual of Mental Disorders, fourth edition (DSM IV) (61).

NINDS-AIREN, ADDTC and ICD 10 criteria include both clinical and radiological data, while DSM IV criteria require only neuroimaging evidence (58-62).

According to the standard NINDS-AIREN criteria (58), the diagnosis of probable $\mathrm{VaD}$ in patients with dementia requires the following conditions: 1) presence of focal neurological signs, such as hemiparesis, lower facial weakness, sensory deficit, hemianopia, dysarthria or Babinski sign; 2) MRI findings of extensive periventricular white matter lesions involving at least $25 \%$ of the total white matter or multiple basal ganglia and white matter lacunes and 3) evidence of a temporal relationship between the onset of dementia and stroke or an abrupt deterioration or fluctuating/stepwise course.

Two types of cases were set through visual assessment on MRI: 1) predominantly "white matter cases" characterized by extending periventricular and deep white matter lesions: extending caps or irregular halo $(>10$ $\mathrm{mm}$ broad) and diffuse confluent hyperintensities ( $>25$ $\mathrm{mm}$ ) and at least 1 lacunar infarct in the deep gray matter; and 2) predominantly "lacunar cases" in which multiple lacunes $>5 \mathrm{~mm}$ in the deep gray matter were associated with at least moderate white matter lesions (57). Additionally, modified NINDS-AIREN criteria for subcortical ischemic vascular dementia require clinical evidence of cerebrovascular disease, i.e. focal signs such as hemiparesis, lower facial weakness, Babinski sign, sensory deficit, dysarthria, gait disorders, extrapyramidal signs (other signs such as early urinary symptoms, behavioral symptoms, dysphagia) and brain imaging evidence of cerebrovascular disease (62).

The ADDTC criteria for possible $\mathrm{VaD}$ include clinical and neuroimaging evidence of Binswanger disease, but without any specification for this "evidence" (63).

ICD10 criteria for $\mathrm{VaD}$ require neuroimaging evidence of cerebrovascular disease "reasonably judged to be etiologically related to dementia" and the presence of focal neurological findings such as unilateral spastic weakness of the limb, unilaterally increased tendon reflexes, extensor plantar response, or pseudobulbar palsy (60).

DSM IV criteria for $\mathrm{VaD}$ require only neuroimaging evidence of cerebrovascular disease judged to be etiologically related to cognitive alterations (61).

In CADASIL, brain MRI shows widespread white matter lesions associated with lacunar infarcts of variable 
extent or number and developing from the third decade (64). The main clinical manifestations include attacks of migraine with aura, recurrent subcortical stroke, mood disturbances, and a progressive cognitive decline leading to dementia (13).

Beside clinical and brain imaging methods, blood tests also play a role in setting the diagnosis of $\mathrm{VaD}$. Malaguarnera et al. (65) investigated the relationship between plasma homocysteine levels and vitamins involved in its metabolism in $\mathrm{AD}$ and $\mathrm{VaD}$. They found that homocysteine levels were singnificantly increased, whereas folate levels were significantly decreased in patients with VaD. Vitamine B12 showed significantly reduced levels only in $\mathrm{AD}$ patients, while vitamin B6 levels were not significantly different between the groups (65).

A most recent study of Chen et al. (66) showed a close correlation between thyroid status and cognitive dysfunction. Serum TT3 and FT3 levels were found to be decreased, whereas serum TSH level was increased, with the decline in cognitive functions. Furthermore,TT3 levels showed a positive correlation, whereas TSH level showed a negative correlation, with the Mini-Mental State Examination (MMSE) scores. The results suggest that thyroid function is associated with cognitive impairments induced by SIVD. Also, thyroid dysfunction could be a risk factor in the development of VaD. Serum TT3 and TSH levels might also be used as biomarkers for $\mathrm{VaD}$.

However, Agarwal et al. (67) have published discrepant results to Chen's study, leaving space for further discussion.

\section{TreatMENT}

According to its multicausal nature, $\mathrm{VaD}$ stands as a difficult condition to treat. Referring to a postulate that vascular pathology likely plays a role in initiating cholinergic neuronal abnormalities in $\mathrm{VaD}$, acetylcholinesterase (AChE) inhibitors are presumed to be an effective therapeutic choice $(5,68)$.

Donepezil use in patients with probable or possible $\mathrm{VaD}$ has shown modest treatment benefits in cognition, but not in global functioning as well (69-71). A study of Roman et al showed that hippocampal size is correlated with the effect of donepezil on cognition, which might be a subject in further investigations of donepezil effectiveness in $\mathrm{VaD}$ treatment (71). However, safety remains a concern because one trial found a significantly higher risk of death in group of patients treated with donepezil, compared to placebo $(1.7 \%$ vs $0 \%)(71,72)$. Studies investigating benefits of Galantamine and Rivastigmine use have shown small improvement in cognitive function, but not in a global performance, neuropsychiatric symptoms or activities of daily living (73-76). They also found greater incidence of gastrointestinal adverse effects (nausea and vomiting) in patients taking Galantamine and Rivastagmine (76, 77). In addition, Rivastigmine use in younger patients showed no benefits and a possible harm (elevated blood pressure, stroke and lethal outcome) (76).

The N-Methyl-D-aspartate (NMDA) receptor antagonist Memantine may have neuroprotective properties and improve cognition. ${ }^{[78]}$ Two trials have shown modest treatment benefits on cognition, but not global functioning in patients with mild to moderate $\operatorname{VaD}(79,80)$. Memantine, not AChE inhibitors, was associated with lower odds of dropouts and adverse events (72).

Antihypertensive medication is associated with a decreased risk of $\mathrm{VaD}$, with a $5 \%$ reduction in $\mathrm{VaD}$ risk yearly $(81,82)$. One cohort study of hypertensive patients with $\mathrm{VaD}$ or mixed dementia showed improved or stabilized cognitive scores with control of systolic blood pressure (BP) in the range of 135 to $150 \mathrm{~mm} \mathrm{Hg}$; interestingly, systolic BP levels below $135 \mathrm{~mm} \mathrm{Hg}$ were associated with steeper cognitive declines (83). Several randomized controlled trials and meta-analyses reported various results of antihypertensive treatment on cognitive function (84-97). Although data suggest that well controlled hypertension might be effective in the secondary prevention of $\mathrm{VaD}$, trials with long-term follow-up are needed.

Despite the fact that decreased levels of high-density lipoproteins and elevated levels of total serum cholesterol and low-density lipoproteins are associated with higher risk of $\mathrm{VaD}$, statin role in $\mathrm{VaD}$ prevention and treatment remains uncertain (5).

Acetylsalicylic acid may prevent $\mathrm{VaD}$ through several mechanisms, including reduced platelet aggregation, decreased circulating $\beta$-amyloid production (derived from platelets), vasodilatation and fewer superoxide radicals. However, its use in $\mathrm{VaD}$ treatment needs to be determined (5).

Apart from medication therapy, surgical treatment of carotid disease is proposed to be effective method in preventing and treating $\mathrm{VaD}$. Although carotid revascularization shows multiple benefits, its role in cognitive improvement is an ongoing debate (98-101). Most of the studies showed some improvement in cognitive status after carotid endarterectomy or stenting, but not in overall cognitive functioning $(100,101)$. Further investigation in this field is needed.

\section{Conclusion}

Vascular dementia is a significant medical problem, with a great social and economic burden. Despite the 
proposed diagnostic criteria and methods, a standard diagnostic set hasn't been established yet. Additionally, none of the current therapeutic methods could stand as a baseline treatment. We are looking forward to the re- sults of ongoing genetic investigations and future clinical trials, that will hopefully give us answers in mechanisms and treatment of vascular dementia.

\section{References}

1. Lobo A, Launer LJ, Fratiglioni L, et al. Prevalence of dementia and major subtypes in Europe: A collaborative study of population-based cohorts. Neurologic Diseases in the Elderly Research Group.Neurology. 2000; 54: S4-9.

2. Wahlund LET, Gauthier S. Vascular Cognitive Impairment in Clinical Practice. Cambridge, UK: Cambridge University Press; 2009.

3. Leblanc GG, Meschia JF, Stuss DT, Hachinski V: Genetics of Vascular Cognitive Impairment The Opportunity and the Challenges.Stroke 2006, 37:248-255.

4. Deborah A. Levine \& Kenneth M. Langa. Vascular Cognitive Impairment: Disease Mechanisms and Therapeutic Implications. Neurotherapeutics (2011) 8:361-373 DOI 10.1007/s13311-011-0047-z

5. Francesco Iemolo, Giovanni Duro, Claudia Rizzo, Laura Castiglia, Vladimir Hachinski and Calogero Caruso. Pathophysiology of vascular dementia. Immunity \& Ageing 2009, 6:13 doi:10.1186/1742-49336-13

6. Hachinski VC, Bowler JV. Vascular dementia. Neurology 1993;43:2159_ 2160; author reply 2160-2151

7. Bowler JV, Steenhuis R, Hachinski V. Conceptual background to vascular cognitive impairment. Alzheimer Dis Assoc Disord 1999;13 Suppl 3:S30-37.

8. O’Brien JT, Erkinjuntti T, Reisberg B, et al. Vascular cognitive impairment. Lancet Neurol 2003;2:89-98.

9. Moorhouse P, Rockwood K. Vascular cognitive impairment: current concepts and clinical developments. Lancet Neurol 2008;7: 246- 255.

10. Strub RL.Vascular dementia. The Ochsner Journal 2003; 5: 40-43.

11. Kostić V. Neurologija: za studente medicine. Medicinski fakultet Univerziteta u Beogradu. 2007; 200.

12. O’Brien JT, Erkinjuntti T, Reisberg B, Roman G, Sawada T, Pantoni L, Bowler JV, Ballard C, DeCarli C, Gorelick PB, Rockwood K, Burns A, Gauthier S, DeKosky ST. Vascular cognitive impairment. Lancet Neurol. 2003;2: 89 -98.

13. Chabriat H, Vahedi K, Iba-Zizen MT, Joutel A, Nibbio A, Nagy TG, Krebs MO, Julien J, Dubois B, Ducrocq X, et al. Clinical spectrum of CADASIL: A study of 7 families. Cerebral autosomal dominant arteriopathy with subcortical infarcts and leukoencephalopathy. Lancet. 1995; 346: $934-939$.

14. Charlton RA, Morris RG, Nitkunan A, Markus HS. The cognitive profiles of CADASIL and sporadic small vessel disease. Neurology. 2006; 66: 1523-1526.

15. Hachinski V. The 2005 Thomas Willis Lecture: stroke and vascular cognitive impairment: a transdisciplinary, translational and transactional approach. Stroke. 2007; 38: 1396.

16. Kivipelto M, Ngandu T, Laatikainen T, Winblad B, Soininen H, Tuomilehto J. Risk score for the prediction of dementia risk in 20 years among middle aged people: a longitudinal, population-based study. Lancet Neurol. 2006;5:735-741.

17. O’Donnell MJ, Xavier D, Liu L, et al. Risk factors for ischaemic and intracerebral haemorrhagic stroke in 22 countries (the INTERSTROKE study): a case-control study. Lancet. 2010;376: 112-123.

18. Yoshitake T, Kiyohara Y, Kato I, et al. Incidence and risk factors of vascular dementia and Alzheimer's disease in a defined elderly Japanese population: the Hisayama Study. Neurology. 1995; 45:1161-1168.

19. Kuller LH, Lopez OL, Jagust WJ, et al. Determinants of vascular dementia in the Cardiovascular Health Cognition Study. Neurology. 2005; 64:1548-1552.

20. Ahtiluoto S, Polvikoski T, Peltonen M, et al. Diabetes, Alzheimer disease, and vascular dementia: a population-based neuropathologic study. Neurology. 2010; 75: 1195-1202.

21. Luchsinger JA, Tang MX, Stern Y, Shea S, Mayeux R. Diabetes mellitus and risk of Alzheimer's disease and dementia with stroke in a multiethnic cohort. Am J Epidemiol. 2001; 154: 635-641.
22. Solomon A, Kivipelto M, Wolozin B, Zhou J, Whitmer RA. Midlife serum cholesterol and increased risk of Alzheimer's and vascular dementia three decades later. Dement Geriatr Cogn Disord. 2009; 28: 75-80.

23. Ravaglia G, Forti P, Lucicesare A, et al. Physical activity and dementia risk in the elderly: findings from a prospective Italian study. Neurology. 2008;70: 1786-1794.

24. Whitmer RA, Gunderson EP, Quesenberry CP, Jr, Zhou J, Yaffe K. Body mass index in midlife and risk of Alzheimer disease and vascular dementia. Curr Alzheimer Res. 2007;4: 103-109.

25. Middleton LE, Yaffe K. Promising strategies for the prevention of dementia. Arch Neurol.2009;66: 1210-1215.

26. Craft S. The role of metabolic disorders in Alzheimer disease and vascular dementia: two roads converged. Arch Neurol. 2009;66:300-305.

27. Wardlaw JM, Sandercock PA, Dennis MS, Starr J. Is breakdown of the blood-brain barrier responsible for lacunar stroke, leukoaraiosis, and dementia? Stroke. 2003;34: 806-812.

28. Murray AM. The brain and the kidney connection: A model of accelerated vascular cognitive impairment. Neurology. 2009;73:916-917.

29. Iadecola C, Park L, Capone C. Threats to the mind: aging, amyloid, and hypertension. Stroke.2009;40: S40-44.

30. Casserly I, Topol E. Convergence of atherosclerosis and Alzheimer's disease: inflammation, cholesterol, and misfolded proteins. Lancet. 2004;363:1139-1146

31. Iadecola C, Gorelick PB. Converging pathogenic mechanisms in vascular and neurodegenerative dementia. Stroke. 2003;34:335-337.

32. Yamamoto $H$, Watanabe $T$, Miyazaki A, et al. High prevalence of Chlamydia pneumoniae antibodies and increased high-sensitive C-reactive protein in patients with vascular dementia. J Am Geriatr Soc.2005;53:583-589.

33. Zuliani G, Guerra G, Ranzini M, et al. High interleukin-6 plasma levels are associated with functional impairment in older patients with vascular dementia. Int J Geriatr Psychiatry. 2007;22:305-311.

34. Honig LS, Tang MX, Albert S, et al. Stroke and the risk of Alzheimer disease. Arch Neurol.2003;60:1707-1712.

35. Langa KM, Foster NL, Larson EB. Mixed dementia: emerging concepts and therapeutic implications.JAMA. 2004;292:2901-2908.

36. Jin YP, Legge S, Ostbye T, Feightner JW, Hachinski V. The reciprocal risks of stroke and cognitive impairment in an elderly population. Alzheimers Dement. 2006;2:171-178.

37. Skoog I, Nilsson L, Palmertz B, Andreasson LA, Svanborg A. A population-based study of dementia in 85-year-olds. $N$ Engl J Med. 1993;328:153-158

38. Puccio D, Novo G, Baiamonte V, et al. Atrial fibrillation and mild cognitive impairment: what correlation? Minerva Cardioangiol. 2009;57:143-150.

39. Purandare N, Voshaar RC, Morris J, et al. Asymptomatic spontaneous cerebral emboli predict cognitive and functional decline in dementia. Biol Psychiatry. 2007;62:339-344.

40. Oijen M, Witteman JC, Hofman A, Koudstaal PJ, Breteler MM. Fibrinogen is associated with an increased risk of Alzheimer disease and vascular dementia. Stroke. 2005;36:2637-2641.

41. Gallacher J, Bayer A, Lowe G, et al. Is sticky blood bad for the brain?: Hemostatic and inflammatory systems and dementia in the Caerphilly Prospective Study. Arterioscler Thromb Vasc Biol. 2010;30:599-604.

42. Joutel A, Corpechot C, Ducros A, Vahedi K, Chabriat H, Mouton P, Alamowitch S, Domenga V, Cecillion M, Marechal E, Maciazek J, Vayssiere C, Cruaud C, Cabanis EA, Ruchoux MM, Weissenbach J, Bach JF, Bousser MG, Tournier-Lasserve E. Notch3 mutations in CADASIL, a hereditary adult-onset condition causing stroke and dementia. Nature. 1996;383:707-710.

43. Ivan CS, Seshadri S, Beiser A, et al. Dementia after stroke: the Framingham Study. Stroke.2004;35:1264-1268. 
44. Hebert R, Lindsay J, Verreault R, Rockwood K, Hill G, Dubois MF. Vascular dementia : incidence and risk factors in the Canadian study of health and aging. Stroke. 2000;31:1487-1493.

45. Baum L, Lam LC, Kwok T, et al. Apolipoprotein E epsilon4 allele is associated with vascular dementia.Dement Geriatr Cogn Disord. 2006;22:301-305

46. Kuller LH, Lopez OL, Newman A, et al. Risk factors for dementia in the cardiovascular health cognition study. Neuroepidemiology. 2003;22:13-22.

47. Barba R, Martinez-Espinosa S, Rodriguez-Garcia E, Pondal M, Vivancos J, Ser T. Poststroke dementia: clinical features and risk factors. Stroke. 2000;31:1494-1501.

48. Leblanc GG, Meschia JF, Stuss DT, Hachinski V. Genetics of vascular cognitive impairment: the opportunity and the challenges. Stroke. 2006;37:248-255.

49. IrenaMartinic-Popovic, Arijana Lovrencic-Huzjan, Vida Demarin Advanced Asymptomatic Carotid Disease and Cognitive Impairment An Understated Link? Stroke Research and Treatment Volume 2012, Article ID 981416, 4 pages

50. M. P. Spencer and J. M. Reid, "Quantitation of carotid stenosis with continuous-wave (C-W) Doppler ultrasound," Stroke, vol. 10, no. 3, pp. 326-330, 1979.

51. A. V. Alexandrov, "The Spencer's curve: clinical implications of a classic hemodynamic model," Journal of Neuroimaging, vol. 17, no. 1, pp. 6-10, 2007.

52. A. S. Turk, I. Chaudry, V. M. Haughton et al., "Effect of carotid artery stenting on cognitive function in patients with carotid artery stenosis: preliminary results," American Journal of Neuroradiology, vol. 29, no. 2, pp. 265-268, 2008.

53. R. Rao, "The role of carotid stenosis in vascular cognitive impairment," Journal of the Neurological Sciences, vol. 203-204, pp. 103-107, 2002.

54. W. Hamster and H. C. Diener, "Neuropsychological changes associated with stenoses or occlusions of the carotid arteries. A comparative psychometric study," European Archives of Psychiatry and Neurological Sciences, vol. 234, no. 1, pp. 69-73, 1984.

55. S. C. Johnston, E. S. O’Meara, T. A. Manolio et al., "Cognitive impairment and decline are associated with carotid artery disease in patients without clinically evident cerebrovascular disease," Annals of Internal Medicine, vol. 140, no. 4, pp. 237-I34, 2004.

56. E. B. Mathiesen, K.Waterloo, O. Joakimsen, S. J. Bakke, E. A. Jacobsen, and K. H. Bønaa, "Reduced neuropsychological test performance in asymptomatic carotid stenosis: the Tromsø Study," Neurology, vol. 62, no. 5, pp. 695-701, 2004.

57. Sarah Benisty, Karen Hernandez, Anand Viswanathan, Sonia Reyes, Annie Kurtz, Michael O'Sullivan, Marie-Germaine Bousser, Martin Dichgans, Hugues Chabriat. Diagnostic Criteria of Vascular Dementia in CADASIL. Stroke 2008;838-844.

58. Roman GC, Tatemichi TK, Erkinjuntti T, Cummings JL, Masdeu JC,Garcia JH, Amaducci L, Orgogozo JM, Brun A, Hofman A, et al. Vascular dementia: Diagnostic criteria for research studies. Report of the ninds-airen international workshop. Neurology. 1993;43:250 -260.

59. Chui HC, Victoroff JI, Margolin D, Jagust W, Shankle R, Katzman R. Criteria for the diagnosis of ischemic vascular dementia proposed by the state of California Alzheimer's disease diagnostic and treatment centers. Neurology. 1992;42:473-480.

60. World Health Organization. TheICD-10 classification of mental and behavioral disorders: Diagnostic criteria for research. Geneva: WHO;1993.

61. American Psychiatric Association. Diagnostic and statistical manual of mental disorders. Washington, DC: American Psychiatric Press; 1994.

62. Erkinjuntti T, Inzitari D, Pantoni L, Wallin A, Scheltens P, Rockwood K, Roman GC, Chui H, Desmond DW. Research criteria for subcortical vascular dementia in clinical trials. J Neural Transm Suppl. 2000;59: $23-30$.

63. Chui HC, Mack W, Jackson JE, Mungas D, Reed BR, Tinklenberg J, Chang FL, Skinner K, Tasaki C, Jagust WJ. Clinical criteria for the diagnosis of vascular dementia: A multicenter study of comparability and interrater reliability. Arch Neurol. 2000;57:191-196.

64. Chabriat H, Levy C, Taillia H, Iba-Zizen MT, Vahedi K, Joutel A, Tournier-Lasserve E, Bousser MG. Patterns of MRI lesions in CADASIL. Neurology. 1998;51:452- 457 .
65. Malaguarnera M, Ferri R, Bella R, Alagona G, Carnemolla A, Pennisi G. Homocysteine, vitamin B12 and folate in vascular dementia and in Alzheimer disease. Clin Chem Lab Med. 2004;42(9):1032-5.

66. Zongsheng Chen, Xianfa Liang, Chunxiu Zhang, Jinling Wang, Gaiping Chen, Hong Zhang, Zhongwu Sun. Correlation of thyroid dysfunction and cognitive impairments induced by subcortical ischemic vascular disease. Brain Behav. 2016 Apr; 6(4): e00452. Published online 2016 Mar 14. doi: 10.1002/brb3.452

67. Rachna Agarwal, Suman Kushwaha, Neelam Chhillar, Alok Kumar, Dharmendra Kumar Dubey, Chandra Bhushan Tripathi. A cross-sectional study on thyroid status in North Indian elderly outpatients with dementia. Ann Indian Acad Neurol. 2013 Jul-Sep; 16(3): 333-337.

68. Roman GC, Kalaria RN. Vascular determinants of cholinergic deficits in Alzheimer disease and vascular dementia. Neurobiol Aging 2006;27:1769-1785

69. Black S, Roman GC, Geldmacher DS, et al. Efficacy and tolerability of donepezil in vascular dementia: positive results of a 24 -week, multicenter, international, randomized, placebocontrolled clinical trial. Stroke 2003;34:2323-2330.

70. Wilkinson D, Doody R, Helme R, et al. Donepezil in vascular dementia: a randomized, placebo-controlled study. Neurology 2003;61:479-486.

71. Roman GC, Salloway S, Black SE, et al. Randomized, placebocontrolled, clinical trial of donepezil in vascular dementia: differential effects by hippocampal size. Stroke 2010;41:1213- 1221.

72. Kavirajan H, Schneider LS. Efficacy and adverse effects of cholinesterase inhibitors and memantine in vascular dementia: a meta-analysis of randomised controlled trials. Lancet Neurol 2007;6:782-792.

73. Erkinjuntti T, Kurz A, Gauthier S, Bullock R, Lilienfeld S, Damaraju $\mathrm{CV}$. Efficacy of galantamine in probable vascular dementia and Alzheimer's disease combined with cerebrovascular disease: a randomised trial. Lancet 2002;359:1283-1290.

74. Auchus AP, Brashear HR, Salloway S, Korczyn AD, De Deyn PP, Gassmann-Mayer C. Galantamine treatment of vascular dementia: a randomized trial. Neurology 2007;69:448-458.

75. Moretti R, Torre P, Antonello RM, Cazzato G, Bava A. Rivastigmine in subcortical vascular dementia: an open 22-month study. J Neurol Sci 2002;203-204:141-146.

76. Ballard C, Sauter M, Scheltens P, et al. Efficacy, safety and tolerability of rivastigmine capsules in patients with probable vascular dementia: the VantagE study. Curr Med Res Opin 2008;24:2561-2574.

77. Craig D, Birks J. Galantamine for vascular cognitive impairment. Cochrane Database Syst Rev 2006:CD004746.

78. Kornhuber J, Weller M, Schoppmeyer K, Riederer P. Amantadine and memantine are NMDA receptor antagonists with neuroprotective properties. J Neural Transm Suppl 1994;43:91-104.

79. Orgogozo JM, Rigaud AS, Stoffler A, Mobius HJ, Forette F. Efficacy and safety of memantine in patients with mild to moderate vascular dementia: a randomized, placebo-controlled trial (MMM 300). Stroke 2002;33:1834-1839

80. Wilcock G, Mobius HJ, Stoffler A. A double-blind, placebocontrolled multicentre study of memantine in mild to moderate vascular dementia (MMM500). Int Clin Psychopharmacol 2002;17:297-305.

81. in't Veld BA, Ruitenberg A, Hofman A, Stricker BH, Breteler MM. Antihypertensive drugs and incidence of dementia: the Rotterdam Study. Neurobiol Aging 2001;22:407-412.

82. Peila R, White LR, Masaki K, Petrovitch H, Launer LJ. Reducing the risk of dementia: efficacy of long-term treatment of hypertension. Stroke 2006;37:1165-1170.

83. Meyer JS, Judd BW, Tawaklna T, Rogers RL, Mortel KF. Improved cognition after control of risk factors for multi-infarct dementia. JAMA 1986;256:2203-2209.

84. Randomised trial of a perindopril-based blood-pressure-lowering regimen among 6,105 individuals with previous stroke or transient ischaemic attack. Lancet 2001;358:1033-1041.

85. Peters R, Beckett N, Forette F, et al. Incident dementia and blood pressure lowering in the Hypertension in the Very Elderly Trial cognitive function assessment (HYVET-COG): a double-blind, placebo controlled trial. Lancet Neurol 2008;7:683-689.

86. Tzourio Forette F, Seux ML, Staessen JA, et al. Prevention of dementia in randomised double-blind placebo-controlled Systolic Hypertension in Europe (Syst-Eur) trial. Lancet 1998;352:1347-1351. 
87. Lithell H, Hansson L, Skoog I, et al. The Study on Cognition and Prognosis in the Elderly (SCOPE): principal results of a randomized double-blind intervention trial. J Hypertens 2003;21:875-886.

88. McGuinness B, Todd S, Passmore P, Bullock R. Blood pressure lowering in patients without prior cerebrovascular disease for prevention of cognitive impairment and dementia. Cochrane Database Syst Rev 2009:CD004034.

89. Forette F, Seux ML, Staessen JA, et al. The prevention of dementia with antihypertensive treatment: new evidence from the Systolic Hypertension in Europe (Syst-Eur) study. Arch Intern Med 2002;162:2046-2052. Vascular Cognitive Impairment 371

90. C, Anderson C, Chapman N, et al. Effects of blood pressure lowering with perindopril and indapamide therapy on dementia and cognitive decline in patients with cerebrovascular disease. Arch Intern Med 2003;163:1069-1075.

91. Bosch J, Yusuf S, Pogue J, et al. Use of ramipril in preventing stroke: double blind randomised trial. BMJ 2002;324:699-702.

92. Qiu C, Winblad B, Fratiglioni L. The age-dependent relation of blood pressure to cognitive function and dementia. Lancet Neurol 2005;4:487-499.

93. Wang LY, Larson EB, Sonnen JA, et al. Blood Pressure and Brain Injury in Older Adults: Findings from a Community-Based Autopsy Study. J Am Geriatr Soc 2009. 57: 1975-1981.

94. Anderson C, Teo K, Gao P, et al. Renin-angiotensin system blockade and cognitive function in patients at high risk of cardiovascular disease: analysis of data from the ONTARGET and TRANSCEND studies. Lancet Neurol 2011; 10: 43-53.
95. Diener HC, Sacco RL, Yusuf S, et al. Effects of aspirin plus extended-release dipyridamole versus clopidogrel and telmisartan on disability and cognitive function after recurrent stroke in patients with ischaemic stroke in the Prevention Regimen for Effectively Avoiding Second Strokes (PRoFESS) trial: a doubleblind, active and placebo-controlled study. Lancet Neurol 2008;7: 875-884.

96. Lopez-Arrieta JM, Birks J. Nimodipine for primary degenerative, mixed and vascular dementia. Cochrane Database Syst Rev 2002:CD000147.

97. Moretti R, Torre P, Antonello RM, Cazzato G, Pizzolato G. Different responses to rivastigmine in subcortical vascular dementia and multi-infarct dementia. Am J Alzheimers Dis Other Demen 2008;23:167-176

98. Radak D, Tanasković S, Matić P, Babić S, Aleksić N, Ilijevski N. Eversion carotid endarterectomy-our experience after 20 years of carotid surgery and 9897 carotid endarterectomy procedures. Ann Vasc Surg. 2012; 26(7):924-8.

99. Radak D, Tanaskovic S, Sagic D, et al. Carotid angioplasty and stenting is safe and effective for treatment of recurrent stenosis after eversion endarterectomy. J Vasc Surg. 2014; 60 (3):645-51.

100. Paola De Rango, MD; Valeria Caso, MD, PhD; Didier Leys, MD; Maurizio Paciaroni, MD; Massimo Lenti, MD; Piergiorgio Cao, MD, FRCS The Role of Carotid Artery Stenting and Carotid Endarterectomy in Cognitive Performance A Systematic Review. Stroke 2008;3116-3127

101. Maarten Plessers, Isabelle Van Herzeele, Frank Vermassen, Guy Vingerhoets. Neurocognitive Functioning after Carotid Revascularization: A Systematic Review. Cerebrovasc Dis Extra 2014;4:132-148 